dr Krzysztof Filipek ${ }^{1}$

\title{
OBSZARY TERENÓW OCHRONY POŚREDNIEJ UJĘĆ WÓD PODZIEMNYCH A PLANY BEZPIECZEŃSTWA WODY - WSKAZÓWKI DLA PRAKTYKÓW
}

https://doi.org/10.18778/8220-655-5.11

\begin{abstract}
Streszczenie: Analiza ryzyka jest koniecznym do opracowania dokumentem, którego wnioski stanowią argument za lub przeciw utworzeniu strefy ochrony pośredniej ujęcia wód podziemnych. Celem analizy ryzyka jest ocena zagrożeń zdrowotnych wynikających ze sposobów zagospodarowania zlewni ujęcia, ocena ryzyka związanego z tymi zagrożeniami oraz analiza barier ochronnych dla ograniczenia skutków. Dopiero na końcu decyduje się kwestia wprowadzenia ewentualnych obostrzeń w gospodarczym korzystaniu z obszarów zlewni ujęcia. Dokumenty hydrogeologiczne są narzędziami bazowymi wykorzystywanymi w metodyce. Identyczne analizy i oceny ryzyka są elementami Planu Bezpieczeństwa Wody (PBW). Praktycznym celem publikacji jest wykazanie możliwości wykorzystania oceny ryzyka z PBW w analizie ryzyka na potrzeby utworzenia strefy. Ważnym wnioskiem z publikacji jest podkreślenie ustawowego wymogu wykonania oceny zagrożeń zdrowotnych dla jakości wody z wykorzystaniem analiz hydrogeologicznych w ramach oceny ryzyka, wykonanej ściśle zgodnie z wymogami normy PN-EN 15975-2.
\end{abstract}

Słowa kluczowe: analiza i ocena ryzyka, zagrożenia zdrowotne, strefa ochrony pośredniej, dokumentacja hydrogeologiczna, Plan Bezpieczeństwa Wody.

\section{Wprowadzenie}

Wyznaczenie i charakterystyka stref ochrony pośredniej ujęć wód podziemnych zawsze były elementami dokumentacji hydrogeologicznej, jednak ustawa Prawo wodne z 2017 roku (Dz.U. z 2021 r., poz. 624) nakazała wykonanie analizy ryzyka dla stwierdzenia potrzeby utworzenia tych stref. Przepisy, mimo że nie zawierają szczegółowej metodyki ani precyzyjnie ustalonego zakresu tejże analizy ryzyka, jasno mówią, kto zobowiązany jest do wykonania dokumentacji, określają także, w artykule 133, ust. 3 ustawy Prawo wodne, jakie elementy powinna obejmować analiza ryzyka. $Z$ cytowanego artykułu wynika wprost, że analiza ryzyka obejmować powinna ,ocenę zagrożeń zdrowotnych z uwzględnieniem czynników negatywnie wpływających na jakość ujmowanej wody”. Dalej w tym akapicie stwierdza się, że tę ocenę zagrożeń zdrowotnych wykonać należy w oparciu o:

- analizy hydrogeologiczne oraz dokumentację hydrogeologiczną;

- identyfikację źródeł zagrożenia [...];

- wyniki badania jakości ujmowanej wody.

$\mathrm{Z}$ treści tegoż artykułu jasno zatem wynika, że chodzi tutaj nie o dokumentację hydrogeologiczną, nie o identyfikację źródeł zagrożenia i nie o wyniki badania jakości wody; wymienione trzy istotne elementy stanowią wylącznie narzędzia pomocnicze do wykonania analizy ryzyka, na co trafnie zwracają uwagę specjaliści (Łyp 2019).

\footnotetext{
${ }^{1}$ FDKF Firma doradcza - gospodarka wodno-ściekowa, Siemianowice Śląskie, k.filipek@ffdkf.pl, ORCID 00000002-4728-1124
} 
Obszary terenów ochrony pośredniej ujęć wód podziemnych a Plany Bezpieczeństwa Wody...

Tak się składa, że analiza ryzyka, związana z oceną ryzyka (rozumianą jako skwantyfikowaną kwintesencję analizy ryzyka), stanowi przedmiot normy PN-EN 15975-2 (PKN 2016). Można i należy zatem przyjąć, iż sformalizowane wytyczne metodyczne do przeprowadzenia analizy ryzyka, wraz z oceną, znajdują się w przytoczonej normie.

Ocena ryzyka stanowi bardzo istotny, kluczowy, element Planów Bezpieczeństwa Wody. Metodyka wykonania Planu opisana jest szczegółowo w dokumencie pn. Podręcznik opracowania Planów Bezpieczeństwa Wodnego (Światowa Organizacja Zdrowia 2009, Główny Inspektorat Sanitarny 2012). Zgodnie z tymi wytycznymi coraz więcej przedsiębiorstw wodociągowych w Polsce, bo w Europie ten proces jest już dużo bardziej zaawansowany, opracowuje Plan Bezpieczeństwa Wody, zdając sobie sprawę z rangi i istoty tego dokumentu.

Plan Bezpieczeństwa Wody obejmuje swoim zasięgiem proces dostawy wody od zlewni ujęcia aż do odbiorcy. Obszar zlewni jest więc tylko jednym z elementów Planu, jednakże ocena ryzyka wykonywana w ramach Planu obejmuje, na równych prawach, także i ten obszar. Skoro zatem obszar zlewni jest wspólnym elementem analizy ryzyka opracowywanej na potrzeby utworzenia strefy ochrony pośredniej oraz oceny ryzyka stanowiącej istotę Planu Bezpieczeństwa Wody, warto by wykonanie dokumentacji dotyczącej ryzyka stanowiło jeden proces z zastosowaniem jednej metodyki i z uwzględnieniem identycznych kryteriów oceny. Przypomnieć bowiem należy, że i w jednym i w drugim dokumencie, tj. analizie ryzyka na potrzeby strefy oraz Planie Bezpieczeństwa Wody, chodzi przede wszystkim o zapewnienie bezpieczeństwa i ochronę jakości (i ilości) wody.

\section{Tło i obszar analizy}

Zlewnia ujęcia wód podziemnych, a w zasadzie część zlewni będąca obszarem spływu wód do ujęcia, którego czas jest równy lub krótszy od 25. lat, stanowi środowisko badawcze analizy i oceny ryzyka. Warto w tym miejscu zauważyć, że w prawodawstwie i w praktyce krajów zachodnich, a także w niektórych polskich publikacjach analizuje się bardziej precyzyjnie zdefiniowane strefy, obejmujące np. obszary spływu o czasie trwania rzędu dni lub miesięcy, co wpływać może na lepszą ochronę zasobów wodnych danego ujęcia (co w interesujący sposób opisuje m.in. B. Łyp 2018a).

Dokumentacja hydrogeologiczna oraz towarzyszące jej analizy (z bardzo dobrze omówioną metodyką, np. w materiale M. Czopa 2019), często wykonane z wykorzystaniem najnowszych narzędzi modelowania numerycznego, bardzo dokładnie ustalają zasięg obszaru ustalonej hydroizohipsy, z uwzględnieniem precyzyjnie wyliczonego czasu wędrówki wody z obecnymi w niej ewentualnymi zanieczyszczeniami przez warstwy izolujące (czas aeracji) oraz przez warstwę wodonośną (czas saturacji). Punktem „startu” omawianej migracji jest dowolny punkt stanowiący ognisko zanieczyszczeń, obecny w omawianej w strefie (w przypadku zanieczyszczeń obszarowych może to być określona powierzchnia presji); punktem docelowym natomiast jest konkretna studnia ujęcia. Analizowanym, lub lepiej powiedzieć - kontrolowanym albo nadzorowanym medium jest konkretny wskaźnik zanieczyszczeń, którym może być albo czynnik mikrobiologiczny, np. bakteria Escherichia coli, albo fizykochemiczny, np. jon azotanowy albo metalu ciężkiego lub substancji ropopochodnej. Pamiętajmy bowiem, że 
zagrożenie zdrowotne, o którym mowa w ustawie Prawo wodne, nie jest tworem niematerialnym, abstrakcyjnym lecz konkretną substancją lub organizmem żywym, np. wirusem lub bakterią.

\section{Istota zagadnienia}

Celem ustawodawcy, nakazującego np. ochronę ujęć wód podziemnych, było stworzenie warunków do prowadzenia działań, które powinny przyczynić się do zmniejszenia lub całkowitego usunięcia presji jakościowej bądź ilościowej na zasoby wodne wykorzystywane jako źródło wody do spożycia przez ludzi (Łyp 2018b). Dlatego kluczowym elementem działań są aspekty zdrowotne, a narzędziami - zakazy, nakazy bądź ograniczenia w stosunku do istniejących lub planowanych albo nawet potencjalnych działań na ściśle zdefiniowanym obszarze zlewni ujęcia wód podziemnych. W związku z tym, że mowa jest, z reguły, o już eksploatowanych ujęciach wód podziemnych, wykonanych na podstawie profesjonalnie opracowanej dokumentacji hydrogeologicznej, nie ma w zasadzie obawy o fundamenty sprawy, dlatego też ustawodawca nie zaleca wykonywanie całej analizy hydrogeologicznej od nowa, ani też nie wspomina o konieczności precyzyjnego modelowania migracji konkretnych, może nawet wszystkich, zidentyfikowanych wskaźników zanieczyszczeń (choć opracowanie takich precyzyjnych analiz nie jest wykluczone), lecz wymaga wyłącznie wykonania analizy ryzyka, która, zgodnie z ustaleniami cytowanej wcześniej normy PN EN 15975-2, może być opracowana metodami półilościowymi, z wykorzystaniem np. matrycy $5 \times 5$ lub nawet $3 \times 3$. Oznacza to w takim razie zgodę na pewną „,uznaniowość” otrzymanych wyników takiej analizy ryzyka. Należy bowiem pamiętać, że wyniki analizy ryzyka stanowią wyłącznie narzędzie w procesie decyzyjnym, na co zresztą wskazuje słowo „może” (a nie np. „musi” lub „powinien”) w odniesieniu do wprowadzenia restrykcji na obszarze strefy ochrony pośredniej. Plan Bezpieczeństwa Wody, mimo że nie odnosi się wprost do kwestii zdrowotnych, to jednak analizuje każdy element całego cyklu dostarczania wody, w tym np. sieci przesyłowe oraz zagadnienia skażeń mikrobiologicznych, np. w kontekście procedur lub systemu monitoringu, a wszystko to $\mathrm{z}$ wykorzystaniem oceny ryzyka. Gdyby zatem przyjąć, że ocena (analiza) ryzyka dla obszaru zlewni oraz dla pozostałych elementów systemu zaopatrzenia $\mathrm{w}$ wodę powinna być wykonana $\mathrm{z}$ wykorzystaniem takiej samej metodyki, w tym także i matryc oceny ryzyka, to nie ma powodu, aby taką ocenę wykonywać dwa razy, tj. osobno w ramach wymogów ustawy Prawo wodne, a osobno jako element Planu Bezpieczeństwa Wody, którego wykonanie, co należy podkreślić, wydaje się być obligatoryjne dla producentów i dostawców, zgodnie z zapisami Dyrektywy Parlamentu Europejskiego i Rady (UE) (2020/2184 z dnia 16 grudnia 2020 r.).

\section{Kluczowe elementy negatywnie wpływające na wody w odniesieniu do terenu ochrony pośredniej, które mogą zostać wykorzystane do analizy i oceny ryzyka} Artykuł 130 (w kontekście art. 140) ustawy Prawo wodne zawiera kluczowe dla oceny ryzyka elementy, tj. listę robót lub czynności, które, jako stanowiące źródło potencjalnych zagrożeń dla jakości wody, mogą podlegać określonym restrykcjom. Zgodnie z normą PN-EN 15975-2 zagrożenia (ich charakterystyka) stanowią bazę do przeprowadzenia skwantyfikowanej oceny 
Obszary terenów ochrony pośredniej ujęć wód podziemnych a Plany Bezpieczeństwa Wody...

ryzyka. Inne elementy normy, tj. np. opis systemu zaopatrzenia w wodę lub sama ocena ryzyka, można założyć, że odnoszą się, w tym przypadku z konieczności, wyłącznie do obszaru zlewni ujęcia, a konkretnie zgodnie z aktualnymi przepisami, do terenu ograniczonego izolinią hydroizohipsy 25. lat. Lista zagrożeń w odniesieniu do terenu ochrony pośredniej wymienia 26 ,zdarzeń", które mogą wpływać na stan wód. Zdarzenia te powinny zostać zatem ocenione przez zespół ekspertów pod względem prawdopodobieństwa wystąpienia oraz spodziewanych skutków także w analizie ryzyka, która ponadto powinna być rozszerzona także o inne specyficzne, różne, potencjalne zdarzenia i sytuacje. I ten element wydaje się kluczowym aspektem oceny ryzyka, której wyniki, przypomnijmy, stanowią podstawę do podjęcia konkretnych decyzji administracyjnych.

Cała procedura (analizy ryzyka) nie kończy się jednak na sporządzeniu listy rankingowej zdarzeń, którym przypisane zostanie określone (wyliczone, ustalone, oszacowane) ryzyko jako iloczyn kilku zdefiniowanych składowych. Nie kończy się nawet na dokonaniu podziału tak otrzymanych ryzyk na trzy grupy, tj. ryzyka akceptowalnego, tolerowalnego i nie do zaakceptowania. Pamiętać bowiem należy, że zgodnie z metodyką, ocenę ryzyka należy przeprowadzić przy założeniu istniejących barier ochronnych, braku barier oraz przy ewentualnych nowych barierach. Trzeba również zwrócić uwagę na zalecane do wprowadzenia narzędzia monitoringu, które także stanowić mogą bardzo konkretną formę barier ochronnych. I dopiero wnioski z tak krótko opisanej, ale rzetelnie przeprowadzonej analizy (oceny) ryzyka mogą stanowić podstawę do rozważenia potrzeby wprowadzenia ograniczeń, nakazów lub zakazów na obszarze potencjalnego terenu ochrony pośredniej ujęcia. Samo utworzenie takiej strefy nie przesądza jeszcze o konieczności wprowadzenia restrykcji, a te restrykcje wcale także nie oznaczają konieczności zaprzestania lub zakazu rozpoczęcia określonych działań. Są bowiem jeszcze wspomniane bariery ochronne, o których niewiele wspomina się tak w normie jak i w Ustawie. Niestety, w dostępnych dokumentach nazwanych „Analizami (Ocenami) ryzyka na potrzeby utworzenia strefy ochrony pośredniej ujęcia X”, ten istotny element jest w zasadzie zupełnie ignorowany. Tak więc wykonana w ten sposób „analiza” nie uwzględniająca barier ochronnych, nie tylko nie spełnia podstawowych wymogów metodycznych lecz także jest niezgodna z wymogami ustawowymi, o czym mało kto zdaje się pamiętać.

\section{Czynniki oddziaływania na jakość wody - aspekty zdrowotne}

Czym są, wymieniane w ustawie Prawo wodne, czynniki zagrożenia zdrowotnego? Można by, w celu udzielenia pełnej odpowiedzi, odnieść się do zapisów Rozporządzenia Ministra Zdrowia w sprawie jakości wody do spożycia przez ludzi (Dz.U. z 2017 r., poz. 2294), a w szczególności do treści załączników, które bardzo precyzyjnie wymieniają owe czynniki, jako ściśle zdefiniowane wskaźniki mikrobiologiczne oraz fizyko-chemiczne (są to konkretne organizmy, jak np. baterie E. coli, enterokoki, albo związki chemiczne lub jony), których obecność w wodzie jest niepożądana lub zakazana, jeśli woda ma być przydatna do spożycia przez ludzi. Zarówno system monitoringu jakości wody prowadzony przez organy Państwowej Inspekcji Sanitarnej jak i system kontroli wewnętrznej, posiadany przez przedsiębiorstwo wodociągów, obejmują kontrolę dokładnie tych elementów (choć nie tylko), które mogą w sposób szkodliwy oddziaływać 
na zdrowie i życie człowieka. I konkretnie te elementy mają stanowić podstawę omawianej analizy ryzyka (Łyp 2019). W tym miejscu pojawia się jednak pewna trudność, wynikająca z faktu, że ocena ryzyka, wykonana zgodnie z omówioną metodyką, jest działaniem w zasadzie szacunkowym, podczas gdy wpływ konkretnych czynników presji na zdrowie człowieka jest mierzalny (chociaż zróżnicowany dla różnych osobników) i wyrażany czasem jako dawka letalna lub dopuszczalne dzienne spożycie, lub w inny sposób. Czasem też, jak w przypadku bakterii paciorkowców, nawet jedna sztuka jest podstawą do stwierdzenia braku przydatności wody do spożycia. Chcąc stwierdzić, jaka ilość danej substancji (szkodliwej) dostaje się (lub może dostać się) do wody, należałoby precyzyjnie ustalić stężenie tej substancji w źródle skażenia, jej ilość, która ulegnie adsorpcji lub dezaktywacji w strefie aeracji oraz wielkość rozcieńczenia w strefie saturacji, zanim dotrze do ujęcia wody podziemnej. Taką precyzyjną odpowiedź daje niemal wyłącznie bardzo dokładne badanie konkretnego przypadku, poparte wynikami analizy fizyko-chemicznej albo/oraz bakteriologicznej wody. Modelowanie natomiast jest jednak wyłącznie modelowaniem, z przyjętym marginesem błędu. Biorąc pod uwagę fakt, że w ocenie ryzyka omawiamy nie tylko przypadki stosunkowo łatwe do skwantyfikowania, które miały miejsce i są dobrze udokumentowane, lecz także i takie, które są wyłącznie hipotetyczne, można przyjąć, że półilościowa metoda, zatwierdzona przez normę, jest wystarczającym, choć z pewnością niedoskonałym narzędziem analizy.

\section{Zagrożenia dla jakości wody wynikające ze sposobów zagospodarowania obszarów zlewni}

Generalizując omówione wcześniej czynniki presji zdrowotnej na jakość wody wynikają głównie (zgodnie z zapisami art. 130. ustawy Prawo wodne) z konkretnych działań prowadzonych na obszarze zlewni. Każde z tych działań charakteryzuje się, niewymienionymi w Ustawie, „specjalistycznymi” czynnikami presji, np.

- $\quad$ wprowadzanie ścieków do wód lub do ziemi (1) - związki biogenne, związki węgla;

- rolnicze wykorzystanie ścieków (2) - azot amonowy, mikroorganizmy;

- stosowanie nawozów sztucznych (4) - sole mineralne, mocznik;

- fermy hodowlane (7) - azot amonowy, mikroorganizmy;

- transport drogowy (8) - związki organiczne, metale ciężkie;

- $\quad$ środki zimowego utrzymania dróg (26) - chlorki;

(liczby w nawiasach oznaczają pozycję na liście ustawowych zagrożeń).

W literaturze dostępne są liczne pozycje (np. Piontek i in. 2012, Klojzy-Karczmarczyk i Mazurek 2017), w których praktycznie wszystkie wymienione czynniki presji zostały poddane szczegółowej analizie ilościowej w odniesieniu do wielkości emisji oraz do ustalenia ilości docierających do warstwy wodonośnej i dalej - do samego ujęcia. Trzeba jednak pamiętać, że omówione przypadki zawierają raczej globalne wielkości zanieczyszczeń, skumulowane np. w trakcie rocznego, typowego użytkowania terenu, a pojedyncze zdarzenia, np. wyciek paliwa z kilkudziesięciotonowej cysterny, omawiane są wyłącznie jako studia hipotetycznych przypadków. Jednakże zasób danych wejściowych jest w pełni dostępny dla chętnych badaczy. Z punktu widzenia metodyki oceny wpływu zdrowotnego wymienionych czynników istotny 
Obszary terenów ochrony pośredniej ujęć wód podziemnych a Plany Bezpieczeństwa Wody...

jest kolejny element analizy, tj. porównanie (lub lepiej - uwzględnienie) takich dodatkowych ilości określonych składników zanieczyszczeń w wodzie surowej, której skład jest doskonale znany z najczęściej wieloletnich badań monitoringowych. I dopiero taka końcowa „mieszanka” stanowi podstawę do oceny możliwości uzdatnienia wody z wykorzystaniem technologii istniejącej w konkretnej stacji uzdatniania wody lub stanowi ewentualnie przyczynek do zaproponowania niezbędnych modyfikacji lub zgodnie z intencją ustawodawcy, jest argumentem do nakazania usunięcia (lub zapobieżenia) takiego zagrożenia. Niezależnie od konieczności przeprowadzenia kartowania analizowanego obszaru zawsze można (i naprawdę warto) skorzystać z bardzo dobrej mapy wrażliwości wód podziemnych na zanieczyszczenia (Duda i in. 2011).

\section{Bariery ochronne - synergia ograniczeń w strefie ochrony pośredniej oraz ustaleń Planu Bezpieczeństwa Wody}

Bariery ochronne, inaczej nazywane także środkami bezpieczeństwa, są z jednej strony niezbędnymi elementami oceny ryzyka, z drugiej zaś naturalnymi sprzymierzeńcami i właścicieli (oraz konsumentów) wody, i użytkowników zlewni, których miałyby dotknąć ewentualne ograniczenia lub zakazy wprowadzone na danym obszarze. Jeśli bowiem przeprowadzona analiza (i ocena) ryzyka wykaże, że pewne zagrożenia charakteryzują się ryzykiem nie do zaakceptowania, to albo takie ryzyko eliminujemy usuwając źródło, albo wprowadzamy skuteczne bariery ochronne. W szerszym kontekście bariery ochronne dotyczą także ryzyka akceptowalnego, gdzie środkiem bezpieczeństwa będzie na przykład kontrola sprawdzająca, czy sytuacja nie uległa pogorszeniu. Tak więc bariery ochronne to element zarządzania ryzykiem. W dużym uproszczeniu można stwierdzić, że to jest najbardziej spektakularny rezultat wykonywanej analizy ryzyka. I to właśnie jest w pewnym sensie ,elegancki” wspólny element analizy ryzyka na potrzeby utworzenia strefy ochrony pośredniej oraz oceny ryzyka jako elementu Planu Bezpieczeństwa Wody, co w obu przypadkach wpływać może pozytywnie na jakość i bezpieczeństwo dostaw wody. Nie ma wielkiej potrzeby omawiania barier ochronnych w postaci eliminacji źródeł problemu, np. zakazu stosowania nawozów sztucznych, zakazu stosowania osadów ściekowych lub nakazu zimowego utrzymania dróg bez stosowania środków chemicznych - są to działania oczywiste i niekiedy konieczne do zastosowania. Jednak konieczność ta musi, zgodnie z przepisami Ustawy, wynikać jednoznacznie z przeprowadzonej analizy ryzyka. W większości jednak przypadków zastosowanie dobrze opracowanych, innych barier ochronnych również może spełnić rolę skutecznej ochrony zasobów wodnych. Pamiętajmy, że mówimy o obszarze, z którego ewentualne zanieczyszczenia, po spełnieniu kilku warunków koniecznych, dostaną się do warstwy wodonośnej w okresie wielu lat, pomijając rzecz jasna przypadki skrajne, obejmujące krótki, np. kilkumiesięczny okres spływu. W takich sytuacjach warto skupić się na skutecznych barierach ochronnych, pamiętając także i o tym, że wprowadzenie restrykcji może wiązać się z wypłatą odszkodowań przez właściciela ujęcia wody, zgodnie z przepisami ustawy Prawo ochrony środowiska (Dz.U. z 2020 r., poz. 1219), np. artykuł 129. Bariery ochronne, co wynika np. z treści podręcznika do opracowania Planu Bezpieczeństwa Wody, mogą mieć charakter działań organizacyjnych, formalno-prawnych, technicznych lub technologicznych. 
Wśród działań organizacyjnych warto wspomnieć np. o żądaniu przez właściciela ujęcia dostępu do informacji o planowanych zmianach w planach zagospodarowania przestrzennego lub o przewidywanych przedsięwzięciach mogących oddziaływać na środowisko. Należy podkreślić, że o to musi zadbać sam właściciel! Innym środkiem ochronnym może być wprowadzenie do systemu monitoringu nowych punktów badawczych (piezometrów) zlokalizowanych np. na trasie potencjalnej migracji zanieczyszczeń w miejscu oddalonym o kilkanaście lat od studni. Dość skuteczną barierą ochronną wydaje się umieszczenie w zakresie wymagań dla planowanej inwestycji, np. stacji benzynowej, konieczności wyposażenia obiektu w odpowiedni system ochronny oraz skuteczną stację osłonową w postaci indywidualnych piezometrów. W przypadku potencjalnych zagrożeń obszarowych, związanych z nieakceptowalnym ryzykiem, skuteczną barierą może być prowadzenie nadzoru nad stosowanymi środkami ochrony roślin lub nawozami naturalnymi albo sztucznymi. Stosowanie takich barier wymaga ścisłego współdziałania właściciela ujęcia, podmiotu prowadzącego określoną działalność gospodarczą na obszarze zlewni oraz instytucji kontrolnych i organów samorządowych. W każdym takim przypadku sprawdza się zasada, że lepiej zapobiegać (i kontrolować) niż leczyć. Z formalnego punktu widzenia po wprowadzeniu wymienionych (nowych) barier ochronnych konieczne jest ponowne przeprowadzenie oceny ryzyka, z góry przewidzianym rezultatem, tj. znaczącym obniżeniem niektórych ryzyk.

\section{Podsumowanie}

Procedury stosowane w analizie ryzyka stanowiącej uzasadnienie dla utworzenia strefy ochrony pośredniej ujęć wód podziemnych powinny być tożsame z metodami oceny ryzyka stanowiącej kluczowy element Planów Bezpieczeństwa Wody. Mimo że w przypadku terenu ochrony pośredniej kluczowym elementem oceny są jasno wyartykułowane (w ustawie Prawo wodne) aspekty zagrożeń zdrowotnych, to bez obawy możemy ten czynnik także potraktować jako kluczowy na potrzeby Planu Bezpieczeństwa Wody. Jest to o tyle istotne, że bariery zaproponowane i w jednej, i w drugiej procedurze, są zbliżone i z pewnością służą temu samemu celowi czyli zapewnieniu bezpieczeństwa wody. Czynniki determinujące wpływ konkretnego zagrożenia, w tym przede wszystkim uwarunkowania hydrogeologiczne, stanowią wyłącznie tło dla samej analizy (oceny) ryzyka. Konkluzja ta powinna stanowić bardzo solidną wytyczną dla wszystkich autorów dokumentacji analizy ryzyka na potrzeby utworzenia terenu ochrony pośredniej ujęć wód podziemnych.

\section{Bibliografia}

Czop M., 2019, Wstępna propozycja zakresu i metodyki analizy ryzyka dla ujęć wód podziemnych wg Stowarzyszenia Hydrogeologów Polskich, [w:] Warsztaty w ramach X Konferencji: Awarie, Monitoring, Budowa i Modernizacja Sieci WOD-KAN, BMP Racibórz, Kielce.

Duda R., Witczak S. i Żurek A., 2011, Mapa wrażliwości wód podziemnych Polski na zanieczyszczenie. 1:500 000. Metodyka i objaśnienia tekstowe, Kraków. 
Obszary terenów ochrony pośredniej ujęć wód podziemnych a Plany Bezpieczeństwa Wody...

Klojzy-Karczmarczyk B. i Mazurek J., 2017, Zanieczyszczenie metalami ciężkimi przypowierzchniowych warstw gruntu w otoczeniu południowej obwodnicy Krakowa, Przegląd Geologiczny, 65(11/2): 1296-1300.

Łyp B., 2018a, Trójstronna ochrona ujęć wód podziemnych słabo izolowanych, Technologia wody, 1(57): 22-26.

Łyp B., 2018b, Strefy ochrony ujęć wód podziemnych, Wydawnictwo Seidel-Przywecki, Sp. z o.o., Warszawa.

Łyp B., 2019, Analiza ryzyka bezpieczeństwa zdrowotnego dla ustanowienia strefy ochrony pośredniej ujęcia wody podziemnej, Technologia wody, 2(64): 52-55.

Piontek M., Walczak B., Czyżewska W., Lechów H., 2012, Miedź, kadm i cynk w pyle drogowym oraz określenie toksyczności tych metali metoda biologiczna, Kosmos, Problemy Nauk Biologicznych, 61(3): 409-415.

Światowa Organizacja Zdrowia, 2009, Podręcznik opracowania Planów Bezpieczeństwa Wodnego. Zarządzanie ryzykiem krok po kroku. Instrukcja dla dostawców wody do spożycia, Główny Inspektorat Sanitarny, Warszawa 2012.

Polska Norma PN-EN 15975-2, 2016, Bezpieczeństwo zaopatrzenia w wodę do spożycia. Wytyczne dotyczace zarządzania kryzysowego i ryzyka. Część 2: zarządzanie ryzykiem, Polski Komitet Normalizacyjny, Warszawa.

Dyrektywa Parlamentu Europejskiego i Rady (UE) 2020/2184 z dnia 16 grudnia 2020 r. w sprawie jakości wody przeznaczonej do spożycia przez ludzi.

Rozporządzenie Ministra Zdrowia z dnia 11 grudnia 2017 r. w sprawie jakości wody do spożycia przez ludzi (Dz.U. z 2017 r., poz. 2294).

Ustawa z 27 kwietnia 2001 r. Prawo ochrony środowiska (Dz.U. z 2020 r., poz. 1219).

Ustawa z 20 lipca 2017 r. Prawo wodne (Dz.U. z 2021 r., poz. 624). 